Article

\title{
Ecological Stoichiometry Homeostasis of Six Microelements in Leymus chinensis Growing in Soda Saline-Alkali Soil
}

\author{
Yuefen $\mathrm{Li}^{1,2, *}$, Heyang Gong ${ }^{1}$, Shujie $\mathrm{Li}^{1, *}$ and Yushu Zhang ${ }^{3}$ \\ 1 College of Earth Sciences, Jilin University, Changchun 130061, China; hygong19@mails.jlu.edu.cn \\ 2 Key Laboratory of Mineral Resources Evaluation in Northeast Asia, Ministry of Land and Resources, \\ Changchun 130061, China \\ 3 Institute of Soil and Fertilizer, Fujian Academy of Agricultural Sciences, Fuzhou 350013, China; \\ yushu.zhang2@unimelb.edu.au \\ * $\quad$ Correspondence: yfli@jlu.edu.cn (Y.L.); lisj@jlu.edu.cn (S.L.); Tel.: +86-137-5600-9975 (Y.L.)
}

Received: 16 April 2020; Accepted: 20 May 2020; Published: 21 May 2020

\begin{abstract}
Soil salinization poses severe threats to grassland ecosystems in various parts of the world, including the Songnen Plain in northeast China. Severe impairment of plant growth in this soil is generally attributed to high soil $\mathrm{pH}$, total alkalinity, and sodium ( $\mathrm{Na}$ ) contents. This paper focuses on the ecological stoichiometry of microelements, which has received much less attention than relations of macroelements, in the soil and plants (specifically Leymus chinensis) growing in it. The results show that the soil's manganese $(\mathrm{Mn})$, zinc $(\mathrm{Zn})$, iron $(\mathrm{Fe})$, copper $(\mathrm{Cu})$, nickel $(\mathrm{Ni})$ and molybdenum (Mo) contents are lower than average in Chinese soils, but only Mn and Zn are severely deficient in L. chinensis. With increases in soil $\mathrm{pH}$, total alkalinity, and $\mathrm{Na}$, the Mo contents in both soil and L. chinensis slightly increase, while contents of the other microelements decline. Homeostasis indices obtained for the six microelements-and $\mathrm{Fe} / \mathrm{Zn}, \mathrm{Fe} / \mathrm{Ni}, \mathrm{Fe} / \mathrm{Cu}$, and $\mathrm{Cu} / \mathrm{Zn}$ ratios-were all between 0.82 and 3.34 (ranging from just below the "plastic" threshold to "weakly homeostatic"). Despite $\mathrm{Zn}$ deficiency in the soil, $\mathrm{Zn}$ appears to have the highest homeostasis of the six elements in L. chinensis (homeostasis indices of $\mathrm{Zn}, \mathrm{Cu}, \mathrm{Ni}, \mathrm{Mn}, \mathrm{Fe}$ and Mo were 3.34, 2.54, 1.86, 1.76, 1.52, and 1.33 , respectively). In addition, the $\mathrm{Cu} / \mathrm{Zn}$ ratio had the highest homeostasis index (1.85), followed by $\mathrm{Fe} / \mathrm{Zn}(1.02), \mathrm{Fe} / \mathrm{Cu}(0.95)$ and $\mathrm{Fe} / \mathrm{Ni}(0.82)$. Appropriate application of $\mathrm{Mn}$ and $\mathrm{Zn}$ fertilizers is recommended to promote the growth and development of L. chinensis in soda saline-alkali soil.
\end{abstract}

Keywords: soda saline-alkali soil; microelement; L. chinensis; ecological stoichiometry; homeostasis; Western Jilin Province

\section{Introduction}

Manganese $(\mathrm{Mn})$, zinc $(\mathrm{Zn})$, iron $(\mathrm{Fe})$, copper $(\mathrm{Cu})$, nickel $(\mathrm{Ni})$, and molybdenum $(\mathrm{Mo})$ are transition and post-transition metals of the fourth and fifth periods of the periodic table [1]. They are often classified as "micronutrients" because they play essential roles at low concentrations in plant growth and ecosystem functions. Mn is an essential cofactor for numerous enzymes in all higher plants [2]. Fe plays a crucial role in many physiological processes in plants, such as nitrogen fixation, respiration, photosynthesis and vitamin synthesis [3]. Zn has several key functions in plants as the only metal present in enzymes of all six major classes, and plays key catalytic, regulatory, and structural roles [4]. $\mathrm{Cu}$ is an essential component of many enzymes and coenzymes [5]. Plants also require trace amounts of $\mathrm{Ni}$ as a cofactor of enzymes including urease [1,6] and Mo for the functionality of enzymes involved in nitrogen metabolism (such as nitrate reductase and nitrogenase), sulfur metabolism, plant hormone biosynthesis, and purine catabolism [7,8]. Similarly, in soils these six elements are essential 
for maintaining environmental quality and soil micronutrients. However, high concentrations are toxic. Thus, either deficits or excessively high levels of the six elements can severely impair the growth, development, and health of plants, microbes, and animals, including humans [9,10].

The Songnen Plain is one of three extensive grasslands in northeast China, and one of the three largest saline-alkali regions in the world. Nearly $24,000 \mathrm{~km}^{2}$ of the plain is salinized, ca. $15.2 \%$ of the total land area [11], and soda saline-alkali soil covers more than $70 \%$ of the total area of saline-alkali soil. Previous studies have shown that both total and available Fe, Mn, Zn contents of soils in this area are low, and corresponding deficiencies in plants appear to reduce the plant communities' productivity [12-15]. Plants must maintain sufficient microelement contents and relatively stable microelement ratios (stoichiometric balances) for healthy growth [16]. However, different plants may have differing needs, and abilities to obtain and maintain specific ranges of contents and ratios of microelements (stoichiometric homeostasis) [17]. As Leymus chinensis is an excellent forage grass with high economic value in the Songnen Plain, it has received substantial scientific attention for many years. Many ecophysiological studies have examined effects of microelement limitation and toxicity on the growth, reproduction, and survival of L. chinensis [12-14,18-20], but few have applied stoichiometric theory [21].

Many scholars are beginning to use ecological stoichiometry for examining balances of multiple chemical substances in ecological interactions and processes involving various elements other than carbon, nitrogen, and phosphorus. However, its application in analyses of most microelements is still in its infancy. A core concept in ecological stoichiometry theory is homeostatic regulation, referring to organisms' ability to maintain internal concentrations of elements at close to physiologically optimal levels, which may strongly differ from the varying concentrations in the environment [21-23]. In the past 20 years, the homeostasis of ecosystems has received increasing attention from ecological and environmental scientists. The importance of stoichiometric homeostasis for maintenance of the structure, functions, and stability of soil-plant systems has also been increasingly recognized. Contents of microelements are also reportedly much less stable than those of macroelements, at least in freshwater invertebrates [21]. However, macroelement homeostasis has received the most attention and appears to be stronger than microelement homeostasis [22,23], but little is known about the compositional homeostasis of microelements.

Several studies $[24,25]$ have shown that the exchangeable sodium percentage (ESP) of soda saline-alkali soils usually exceeds $20 \%$, their pH exceeds 8.5 (10-11 in extreme cases), and the main salts in them are $\mathrm{NaHCO}_{3}$ and $\mathrm{Na}_{2} \mathrm{CO}_{3}$. Furthermore, they usually have poor structure, permeability and nutrient retention capacities. In addition, strong $\mathrm{Na}$ competition reduces plants' absorption of potassium, phosphorus, and other elements. Strong alkaline soil environment can also adversely affect nutrient availability by impairing microbial activity, thus promoting deficiencies of $\mathrm{Fe}, \mathrm{B}, \mathrm{Al}, \mathrm{Cu}, \mathrm{Mn}$, and Zn [5,26], thereby affecting plants' nutritional status and stoichiometry. However, stoichiometric characteristics of plants have some plasticity, and the plasticity of their responses to environmental factors may directly affect their ability to grow and adapt to their environments [22,23,27].

In efforts to understand the stoichiometric characteristics of microelements in L. chinensis plants growing in soda saline-alkali soil on the Songnen plain, we have investigated: the microelement contents and ratios in the plants and soil; effects of soil $\mathrm{pH}$, total alkalinity, and $\mathrm{Na}$ contents on the microelements; and microelement homeostasis of L. chinensis. The results are expected to strengthen scientific foundations for refining precision fertilization, based on the abundance or deficiency of microelements, and provide indications of the mechanisms involved in the adaptation of plants (particularly L. chinensis) to saline-alkali habitats in grassland ecosystems. 


\section{Materials and Methods}

\subsection{Description of the Study Area}

The study area is located in the southwest part of the Songnen plain in western Jilin Province $\left(123^{\circ} 09^{\prime} \mathrm{E}-124^{\circ} 22^{\prime} \mathrm{E}, 44^{\circ} 57^{\prime} \mathrm{N}-45^{\circ} 46^{\prime} \mathrm{N}\right)$, where there is a semi-arid and sub-humid continental monsoon climate with four distinct seasons [28]. Mean annual precipitation ranges between 400-500 mm and the mean annual evaporation ranges between 1500-1900 mm, with a maximum temperature of $23{ }^{\circ} \mathrm{C}$ in July and minimum temperature of $-17.5^{\circ} \mathrm{C}$ in January. As western Jilin Province is a closed-flow area, with a high degree of groundwater mineralization and salt accumulation, saline-alkali soils have fully developed in this area. The plant communities are mainly dominated by L. chinensis, accompanied by Calamagrostis epigeios, Arundinella hirta, Chloris virgate, Puccinellia tenuiflora, Suaeda glauca, and various other grasses. Soil types include light chernozem, meadow, sandy, chernozem, alkali, and chestnut soils. The location of the study area is shown in Figure 1.

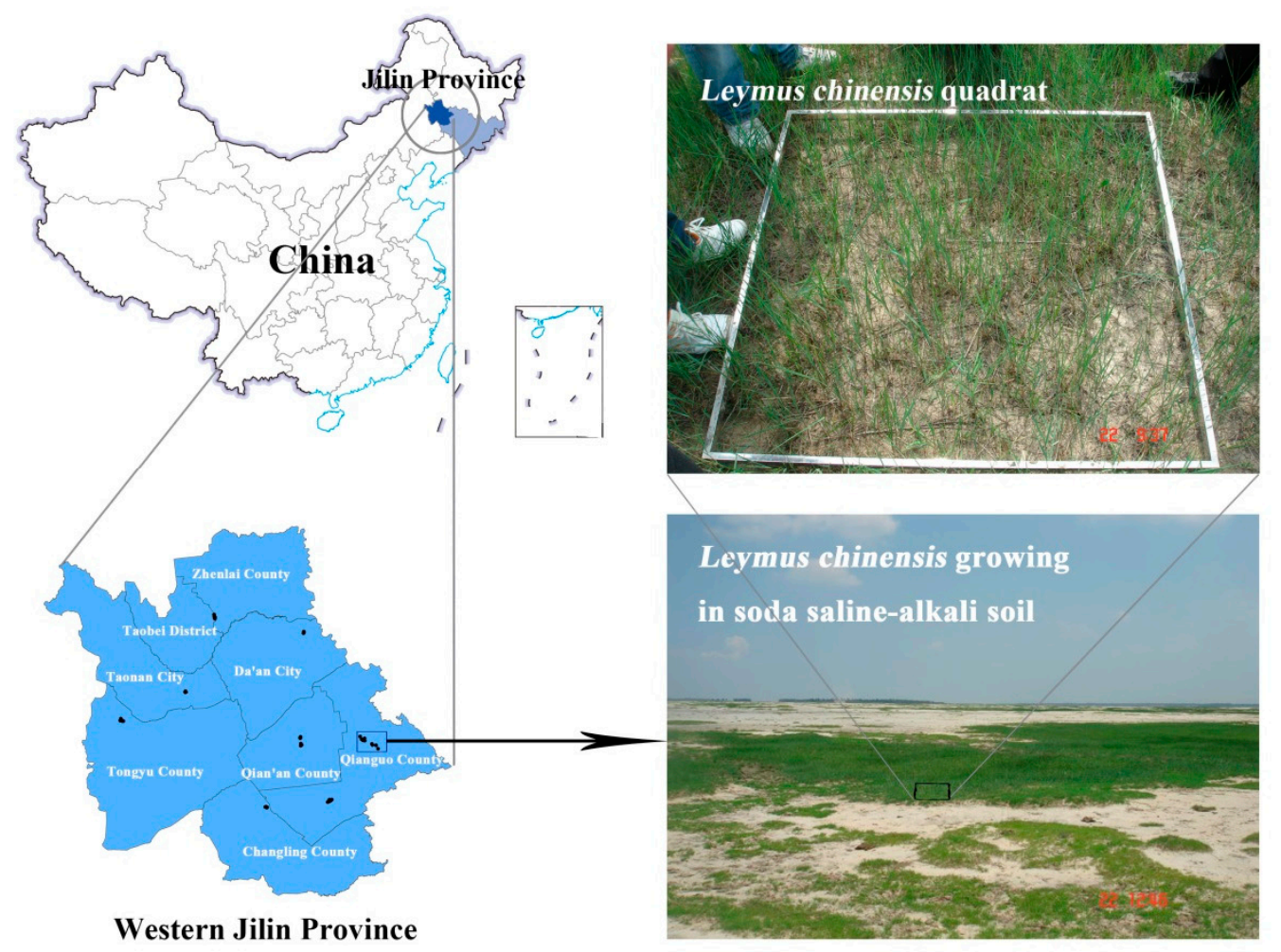

Figure 1. Location of the study area in China and photographs showing the salinization of the soil and associated degradation of the L. chinensis grassland.

\subsection{Sample Collection and Testing Methods}

The reasons why L. chinensis was selected for this study include its wide distribution in the study area and ability to grow normally in environments with a wide $\mathrm{pH}$ range. To investigate effects of soda saline-alkali soil on microelement homeostasis of L. chinensis in the area, we followed recommendations to select sampling sites that are flat and have similar elevations and soil types [29]. At these sites (in Da'an City, Taonan City, Changling County, Tongyu County, Zhenlai County, Qian'an County, and Qianguo County of Western Jilin Province), 67 quadrats $(100 \times 100 \mathrm{~cm})$ were laid out, as summarized in Table 1. Plant samples were collected in June 2017, by cutting off aboveground parts of L. chinensis plants with scissors, then manually removing extraneous materials (other plants, etc.). The cleaned L. chinensis samples were then placed in numbered sample bags. Soil samples were taken from the 0 to $20 \mathrm{~cm}$ soil layer at five randomly selected positions in each sampling quadrat using a $3.5 \mathrm{~cm}$ diameter stainless steel soil sampler. These samples were carefully mixed to form a composite 
sample for each quadrat, which was then air-dried in the laboratory. Visible plant roots, debris, and stones were removed. The samples were then quartered to reduce their volume and stored in suitably labeled sample bags.

Table 1. Sample description and soil chemical properties.

\begin{tabular}{|c|c|c|c|c|c|c|}
\hline \multirow{2}{*}{ Sampling Sites } & \multirow{2}{*}{$\begin{array}{c}\text { Number of } \\
\text { Quadrats }\end{array}$} & \multirow{2}{*}{ Central Location } & \multicolumn{2}{|c|}{ Soil pH } & \multicolumn{2}{|c|}{ Total Alkalinity } \\
\hline & & & Range & Mean & Range & Mean \\
\hline $\begin{array}{l}\text { Da'an } \\
\text { City }\end{array}$ & 19 & $\begin{array}{l}123^{\circ} 58^{\prime} 34^{\prime \prime} \mathrm{E} \\
45^{\circ} 38^{\prime} 21^{\prime \prime} \mathrm{N}\end{array}$ & $8.26-9.87$ & 8.82 & $446.52-3615.66$ & 969.99 \\
\hline $\begin{array}{l}\text { Taonan } \\
\text { City }\end{array}$ & 4 & $\begin{array}{l}122^{\circ} 56^{\prime} 16^{\prime \prime} \mathrm{E} \\
45^{\circ} 14^{\prime} 28^{\prime \prime} \mathrm{N}\end{array}$ & $8.39-8.78$ & 8.54 & $439.20-830.52$ & 645.42 \\
\hline $\begin{array}{l}\text { Changling } \\
\text { County }\end{array}$ & 6 & $\begin{array}{l}123^{\circ} 41^{\prime} 10^{\prime \prime} \mathrm{E} \\
44^{\circ} 32^{\prime} 08^{\prime \prime} \mathrm{N}\end{array}$ & $8.20-8.56$ & 8.34 & $256.20-468.48$ & 336.72 \\
\hline $\begin{array}{l}\text { Tongyu } \\
\text { County }\end{array}$ & 5 & $\begin{array}{l}122^{\circ} 23^{\prime} 22^{\prime \prime} \mathrm{E} \\
45^{\circ} 02^{\prime} 39^{\prime \prime} \mathrm{N}\end{array}$ & $8.34-8.58$ & 8.48 & $484.80-684.12$ & 571.21 \\
\hline $\begin{array}{l}\text { Zhenlai } \\
\text { County }\end{array}$ & 8 & $\begin{array}{l}123^{\circ} 10^{\prime} 19^{\prime \prime} \mathrm{E} \\
45^{\circ} 43^{\prime} 08^{\prime \prime} \mathrm{N}\end{array}$ & $8.53-9.76$ & 9.23 & $322.08-1475.76$ & 934.84 \\
\hline $\begin{array}{l}\text { Qian'an } \\
\text { County }\end{array}$ & 9 & $\begin{array}{l}123^{\circ} 58^{\prime} 15^{\prime \prime} \mathrm{E} \\
44^{\circ} 58^{\prime} 27^{\prime \prime} \mathrm{N}\end{array}$ & $8.22-8.56$ & 8.34 & $622.20-812.52$ & 712.89 \\
\hline $\begin{array}{l}\text { Qianguo } \\
\text { County }\end{array}$ & 16 & $\begin{array}{l}124^{\circ} 30^{\prime} 18^{\prime \prime} \mathrm{E} \\
44^{\circ} 55^{\prime} 44^{\prime \prime} \mathrm{N}\end{array}$ & 7.93-8.47 & 8.21 & $146.40-589.26$ & 426.39 \\
\hline
\end{tabular}

$\mathrm{Mn}, \mathrm{Fe}, \mathrm{Ni}, \mathrm{Cu}, \mathrm{Mo}$, and $\mathrm{Zn}$ levels in the soil and L. chinensis samples were assayed by the LY/T 1256-1999 and LY/T 1270-1999 methods, respectively, and quantitatively determined by inductively coupled plasma atomic emission spectroscopy (ICP-AES, ICPS-7500). Soil total alkalinity was estimated by determining and summing contents of carbonate $\left(\mathrm{CO}_{3}^{2-}\right)$, ions + bicarbonate $\left(\mathrm{HCO}_{3}^{-}\right)$, and ions [30]. Soil $\mathrm{pH}$ was measured in 1:2.5 (w/v) soil/water extracts.

\subsection{Data Analysis}

Pearson correlation analysis was used to estimate correlations between contents of all pairs of the six microelements. Statistical analyses were performed using Stata software (version 16.0). The microelements' homeostasis was quantified in terms of the homeostasis index $\left(y=c x^{\frac{1}{H}}\right)$ using Matlab (R2016a, The Math Works Inc. Natick, MA, USA), where $x$ is the measured content of a microelement in the soil, $y$ is the measured content of the same microelement in a plant (here L. chinensis), $c$ is a constant, and $H$ is the homeostasis index. The results were visualized using Sigmaplot 12.5 (Systat Software, Inc. Germany). In the following text, $H x$ refers to the homeostatic index obtained for element $x$.

\section{Results}

\subsection{Microelement Contents and Ratios in Soda Saline-Alkali Soil and L. chinensis}

Average contents of the six microelements in the soil and L. chinensis varied widely (Table 2). Their contents in the soil declined in the order $\mathrm{Fe}>\mathrm{Mn}>\mathrm{Zn}>\mathrm{Ni}>\mathrm{Cu}>\mathrm{Mo}$, while in L. chinensis they declined in the order $\mathrm{Fe}>\mathrm{Mn}>\mathrm{Zn}>\mathrm{Cu}>\mathrm{Ni}>\mathrm{Mo}$. As shown in Table 2, average total $\mathrm{Mn}, \mathrm{Fe}, \mathrm{Ni}, \mathrm{Cu}, \mathrm{Zn}$, and $\mathrm{Mo}$ contents of the soda saline-alkali soil were $294,14,150,21.0,15.3,34.9$, and $0.51 \mathrm{mg} / \mathrm{kg}$, respectively; considerably lower than average values $(710,29,400,40,22,100$, and $1.7 \mathrm{mg} / \mathrm{kg}$, respectively) in Chinese agricultural soil [31,32].

Generally, Mn, Fe, Ni, Cu, Zn, and Mo contents of healthy plants are reportedly 50-200, 100-300, 1-5, 5-20, 25-150, and 0.1-1.0 mg/kg, respectively [33,34]. As shown in Table 2, average contents of these elements in the sampled L. chinensis plants were $32.9,421,1.30,7.06,17.8$, and $0.77 \mathrm{mg} / \mathrm{kg}$, respectively. Thus, they had abundant $\mathrm{Fe}$, ample $\mathrm{Ni}$ and $\mathrm{Mo}$, low $\mathrm{Cu}$ contents, and substantial deficiencies in $\mathrm{Mn}$ and $\mathrm{Zn}$. 
Pearson correlation analysis showed there were very significant correlations $(p<0.01)$ between nine pairs of the measured elements (Fe and $\mathrm{Mn}, \mathrm{Ni}$ and $\mathrm{Mn}, \mathrm{Ni}$ and $\mathrm{Fe}, \mathrm{Cu}$ and $\mathrm{Mn}, \mathrm{Fe}$ and $\mathrm{Cu}, \mathrm{Cu}$ and $\mathrm{Ni}, \mathrm{Zn}$ and $\mathrm{Mn}, \mathrm{Fe}$ and $\mathrm{Zn}, \mathrm{Cu}$ and $\mathrm{Zn}$ ) in both soil and L. chinensis (Table 3).

Table 2. Microelement contents in the soda saline-alkali soil and L. chinensis $(n=67)$.

\begin{tabular}{ccccccc}
\hline \multicolumn{2}{c}{ Microelements } & Mean & $\begin{array}{c}\text { Standard } \\
\text { Deviation }\end{array}$ & $\begin{array}{c}\text { Coefficient } \\
\text { of Variation }\end{array}$ & Maximum & Minimum \\
\hline \multirow{6}{*}{ Soil } & $\mathrm{Mn}(\mathrm{mg} / \mathrm{kg})$ & 293.61 & 65.45 & 0.22 & 445.08 & 141.76 \\
& $\mathrm{Fe}(\mathrm{mg} / \mathrm{kg})$ & $14,150.09$ & 3546.30 & 0.25 & $27,797.17$ & 6745.10 \\
& $\mathrm{Ni}(\mathrm{mg} / \mathrm{kg})$ & 21.02 & 6.20 & 0.29 & 40.38 & 7.41 \\
& $\mathrm{Cu}(\mathrm{mg} / \mathrm{kg})$ & 15.26 & 4.28 & 0.28 & 27.25 & 7.85 \\
& $\mathrm{Zn}(\mathrm{mg} / \mathrm{kg})$ & 34.87 & 11.40 & 0.33 & 91.50 & 15.02 \\
& $\mathrm{Mo}(\mathrm{mg} / \mathrm{kg})$ & 0.51 & 0.09 & 0.18 & 0.73 & 0.30 \\
\hline \multirow{6}{*}{ L. chinensis } & $\mathrm{Mn}(\mathrm{mg} / \mathrm{kg})$ & 32.90 & 14.24 & 0.43 & 73.26 & 3.37 \\
& $\mathrm{Fe}(\mathrm{mg} / \mathrm{kg})$ & 421.46 & 315.66 & 0.75 & 2301.99 & 176.87 \\
& $\mathrm{Ni}(\mathrm{mg} / \mathrm{kg})$ & 1.30 & 0.96 & 0.74 & 6.11 & 0.29 \\
& $\mathrm{Cu}(\mathrm{mg} / \mathrm{kg})$ & 7.06 & 2.47 & 0.35 & 15.52 & 3.30 \\
& $\mathrm{Zn}(\mathrm{mg} / \mathrm{kg})$ & 17.78 & 6.17 & 0.35 & 40.64 & 7.68 \\
$\mathrm{Mo}(\mathrm{mg} / \mathrm{kg})$ & 0.77 & 0.39 & 0.51 & 2.14 & 0.29 \\
\hline
\end{tabular}

Table 3. Correlation coefficients of the six microelements in the soil and L. chinensis $(n=67)$.

\begin{tabular}{|c|c|c|c|c|c|}
\hline Soil & Mn & $\mathrm{Fe}$ & $\mathrm{Ni}$ & $\mathrm{Cu}$ & Zn \\
\hline $\mathrm{Fe}$ & $0.9212 *(0.0000)$ & & & & \\
\hline $\mathrm{Ni}$ & $0.8055 *(0.0000)$ & $0.8708 *(0.0000)$ & & & \\
\hline $\mathrm{Cu}$ & $0.6990 *(0.0000)$ & $0.8080 *(0.0000)$ & $0.9104 *(0.0000)$ & & \\
\hline $\mathrm{Zn}$ & $0.5770 *(0.0000)$ & $0.6254 *(0.0000)$ & $0.6134 *(0.0000)$ & $0.6136 *(0.0000)$ & \\
\hline Mo & $0.5274 *(0.0000)$ & $0.4542 *(0.0001)$ & $0.4359 *(0.0002)$ & $0.4176 *(0.0004)$ & $0.3111(0.0104)$ \\
\hline L. chinensis & Mn & $\mathrm{Fe}$ & $\mathrm{Ni}$ & $\mathrm{Cu}$ & $\mathrm{Zn}$ \\
\hline $\mathrm{Fe}$ & $0.4155 *(0.0005)$ & & & & \\
\hline $\mathrm{Ni}$ & $0.3158 *(0.0092)$ & $0.4593 *(0.0001)$ & & & \\
\hline $\mathrm{Cu}$ & $0.4704 *(0.0001)$ & $0.4425 *(0.0002)$ & $0.4251 *(0.0003)$ & & \\
\hline $\mathrm{Zn}$ & $0.3656 *(0.0023)$ & $0.4748 *(0.0000)$ & $0.3068(0.0116)$ & $0.5051 *(0.0000)$ & \\
\hline Mo & $-0.1692(0.1710)$ & $0.1075(0.3863)$ & $-0.1614(0.1918)$ & $-0.1308(0.2914)$ & $-0.1292(0.2976)$ \\
\hline
\end{tabular}

As shown in Table 4, statistical analysis of the microelement ratios revealed that coefficients of variations $(\mathrm{CVs})$ of all the soil microelement ratios were less than $22 \%$, indicating that regional variations are small and the soda saline-alkali soil has very low heterogeneity. CVs of the plant microelement ratios were larger than those of the soil, possibly because plant stoichiometry may be related to plant biomass [35]. For example, a previous study of $\mathrm{Mn}, \mathrm{Fe}, \mathrm{Cu}$, and $\mathrm{Zn}$ dynamics in the soil and L. chinensis in grassland in northeast China showed that contents of all four of these elements were lower in L. chinensis in June and July than in May [36]. Analyses of microelement deficiency thresholds for mature leaves of various plants have also indicated that $\mathrm{Mn}$ is generally the limiting nutrient when $\mathrm{Fe} / \mathrm{Mn}>2.5$ or $\mathrm{Mn} / \mathrm{Cu}<5$ [37]. $\mathrm{Cu}$ is the limiting nutrient when $\mathrm{Fe} / \mathrm{Cu}>12.5$, and plant growth is limited by Zn when $\mathrm{Fe} / \mathrm{Zn}>2.5$ or $\mathrm{Cu} / \mathrm{Zn}>0.2$. Ni is widespread in the lithosphere and biosphere, so plants growing under natural conditions rarely develop Ni deficiency symptoms. Therefore, the data presented in Table 4 indicate that $\mathrm{L}$. chinensis growth is limited by $\mathrm{Zn}, \mathrm{Mn}$, and $\mathrm{Cu}$ in the soda saline-alkali soil, but the $\mathrm{Cu}$ content $(7.06 \mathrm{mg} / \mathrm{kg})$ is within the range permitting normal growth. 
Table 4. Microelement ratios in the soil and L. chinensis $(n=67)$.

\begin{tabular}{ccccccc}
\hline Microelement Ratio & Mean & Standard Deviation & Coefficient of Variation & Maximum & Minimum \\
\hline & $\mathrm{Fe} / \mathrm{Mn}$ & 48.22 & 4.21 & 0.09 & 62.62 & 37.78 \\
$\mathrm{Mn} / \mathrm{Ni}$ & 14.45 & 2.69 & 0.19 & 22.46 & 9.85 \\
$\mathrm{Fe} / \mathrm{Ni}$ & 691.75 & 113.35 & 0.16 & 1057.09 & 496.98 \\
$\mathrm{Mn} / \mathrm{Cu}$ & 19.88 & 4.29 & 0.22 & 34.03 & 10.62 \\
Soil & $\mathrm{Fe} / \mathrm{Cu}$ & 948.94 & 167.37 & 0.18 & 1467.69 & 664.99 \\
& $\mathrm{Cu} / \mathrm{Ni}$ & 0.74 & 0.10 & 0.13 & 1.14 & 0.52 \\
$\mathrm{Mn} / \mathrm{Zn}$ & 8.75 & 1.78 & 0.20 & 13.83 & 3.21 \\
$\mathrm{Fe} / \mathrm{Zn}$ & 418.65 & 73.82 & 0.18 & 609.61 & 146.33 \\
$\mathrm{Cu} / \mathrm{Zn}$ & 0.45 & 0.08 & 0.17 & 0.59 & 0.13 \\
\hline $\mathrm{Fe} / \mathrm{Mn}$ & 15.46 & 14.03 & 0.91 & 94.20 & 4.88 \\
$\mathrm{Mn} / \mathrm{Ni}$ & 33.53 & 20.94 & 0.62 & 116.25 & 5.20 \\
$\mathrm{Fe} / \mathrm{Ni}$ & 410.69 & 227.78 & 0.55 & 1196.52 & 93.39 \\
$\mathrm{Mn} / \mathrm{Cu}$ & 4.89 & 2.26 & 0.46 & 11.99 & 0.71 \\
$\mathrm{Fe} / \mathrm{Cu}$ & 60.22 & 33.73 & 0.56 & 198.55 & 29.17 \\
$\mathrm{Cu} / \mathrm{Ni}$ & 7.49 & 4.23 & 0.57 & 22.98 & 1.30 \\
$\mathrm{Mn} / \mathrm{Zn}$ & 1.97 & 0.98 & 0.50 & 5.67 & 0.16 \\
$\mathrm{Fe} / \mathrm{Zn}$ & 24.07 & 12.90 & 0.54 & 69.65 & 9.85 \\
$\mathrm{Cu} / \mathrm{Zn}$ & 0.42 & 0.16 & 0.37 & 0.92 & 0.20 \\
\hline
\end{tabular}

\subsection{Effects of Soil pH, Total Alkalinity and Na on Microelement Contents}

Soil pH generally plays a major role in micronutrient availability [5], and high salt contents affect plants' health by reducing soil porosity, thereby impairing the movement of oxygen and water near roots. High $\mathrm{Na}^{+}$contents also have adverse physiological effects on plants through toxicity to essential enzymes [38-40], and nutritional stresses associated with long-term exposure to salt can severely impair plants' growth [41,42]. For example, Na competitively inhibits $\mathrm{K}, \mathrm{Ca}$, and $\mathrm{Mg}$ uptake, thereby inducing their deficiencies [42]. It also raises soil $\mathrm{pH}$, thereby reducing the availability of $\mathrm{Fe}, \mathrm{Mn}, \mathrm{Zn}$, and $\mathrm{Cu}$, when relevant $\mathrm{pH}$ thresholds are exceeded [43]. For such reasons, it is generally accepted that plants' tolerance of Na depends on their ability to exclude it and maintain elemental homeostasis.

As shown in Figures 2 and 3, soil contents of all the measured microelements except Mo tended to decrease with increasing soil $\mathrm{pH}$ and total alkalinity. This is consistent with expectations because increases in $\mathrm{pH}$ generally increase adsorption of Mo in the soil, but reduce adsorption of the other microelements.

In accordance with findings that $\mathrm{Na}$ is the main element that impedes plant growth in the soil of the study area [19], contents of four of the microelements in L. chinensis tended to decrease with increases in the soil's Na content (Figure 4). The exceptions were Mo and Zn, contents of which slightly increased with increasing $\mathrm{Na}$ content in the soil. 

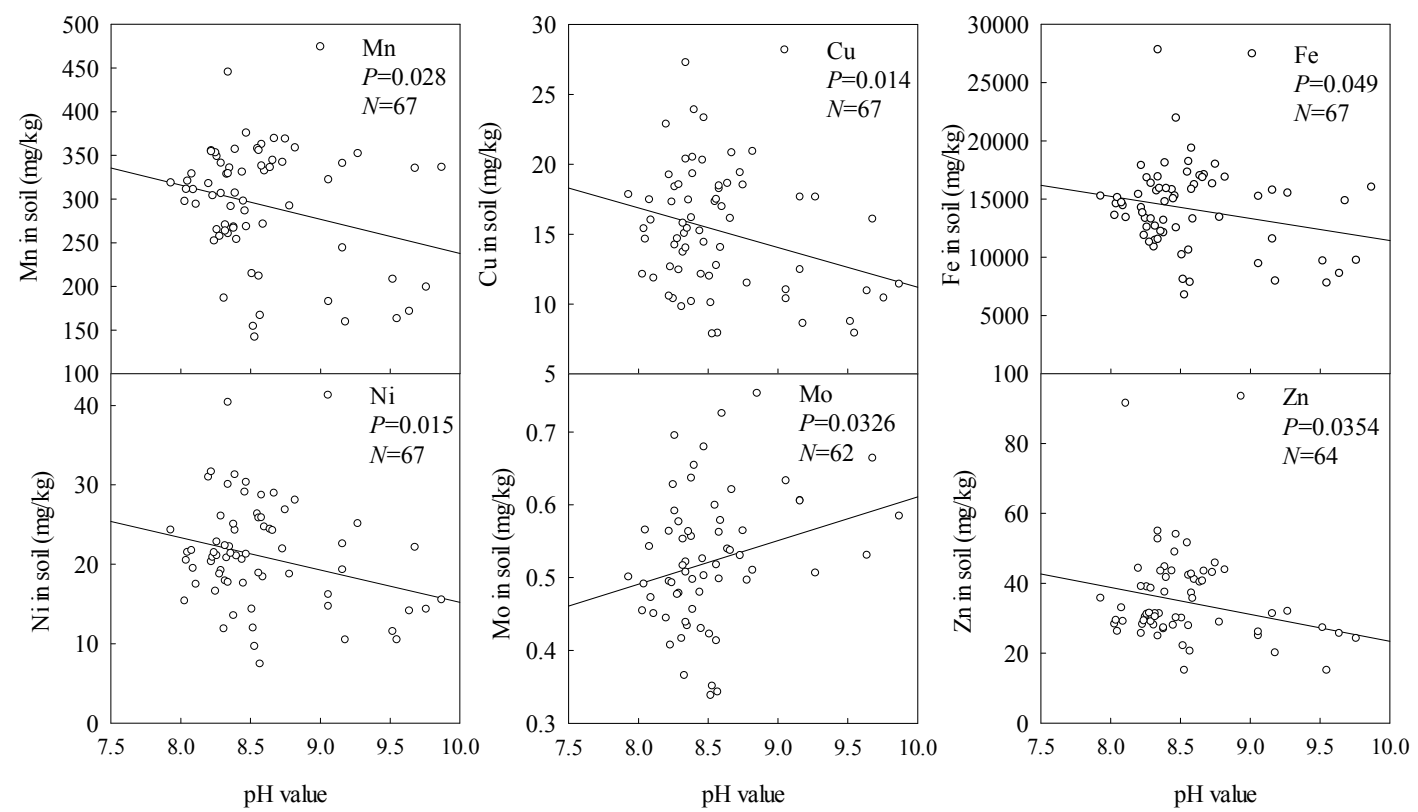

Figure 2. Effects of soil $\mathrm{pH}$ on soil microelement contents.
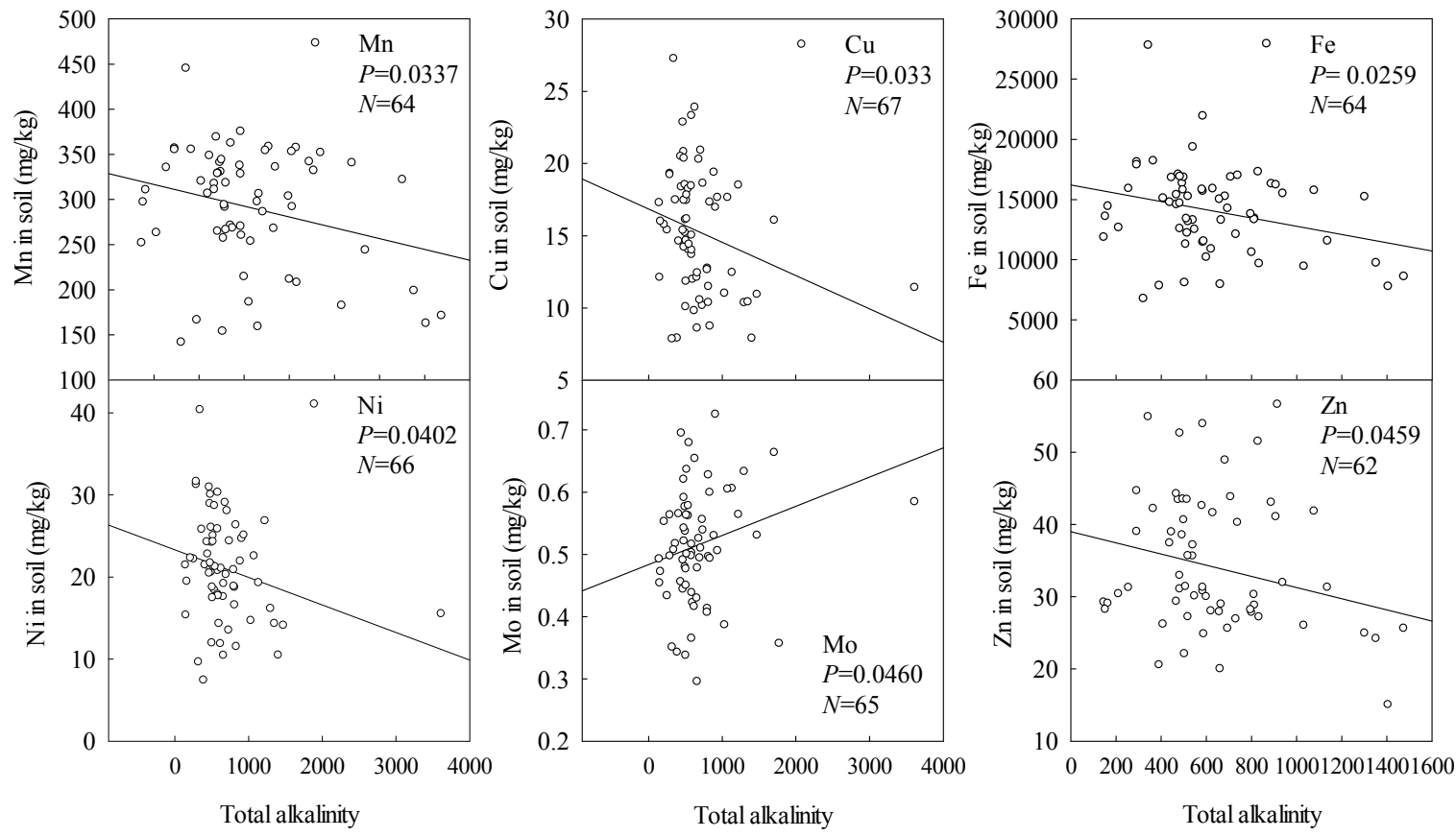

Figure 3. Effects of soil total alkalinity on soil microelement contents. 

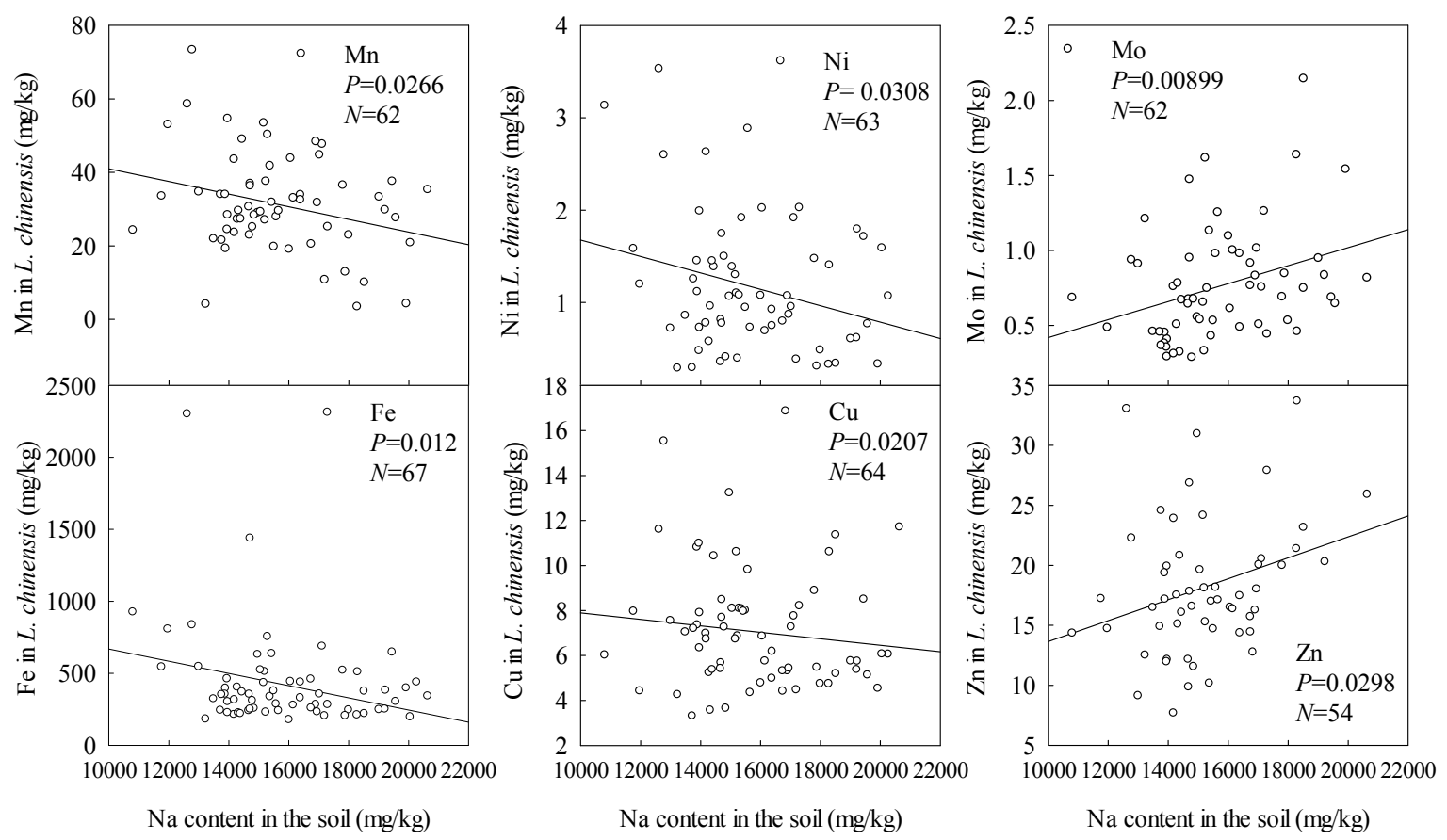

Figure 4. Effects of soil Na content on microelement contents in L. chinensis.

\subsection{Microelement Homeostasis of L. chinensis}

As shown in Figure 5, we found substantial variations among the microelements' stoichiometric homeostasis in L. chinensis, although we obtained stoichiometric homeostasis indices $(H)>0$ for all six microelements. They declined in the order $H_{\mathrm{Zn}}(3.34)>H_{\mathrm{Cu}}(2.54)>H_{\mathrm{Ni}}(1.86)>H_{\mathrm{Mn}}(1.76)>H_{\mathrm{Fe}}$ (1.52) $>H_{\mathrm{Mo}}$ (1.33). $H$ values $>4,2-4,1.33-2$, and $<1.33$ have been classified as "homeostatic," "weakly homeostatic," "weakly plastic," and "plastic," respectively [44]. According to this scheme, Zn and Cu are "weakly homeostatic," Ni, Mn, Fe and Mo are "weakly plastic" in L. chinensis in the study area. Of the nine pairs of microelement ratios considered, only $H_{\mathrm{Fe} / \mathrm{Zn}}, H_{\mathrm{Fe} / \mathrm{Ni}}, H_{\mathrm{Fe} / \mathrm{Cu}}$ and $H_{\mathrm{Cu} / \mathrm{Zn}}$ exceeded zero (Figure 6), and declined in the order $H_{\mathrm{Cu} / \mathrm{Zn}}(1.85)>H_{\mathrm{Fe} / \mathrm{Zn}}(1.02)>H_{\mathrm{Fe} / \mathrm{Cu}}(0.95)>H_{\mathrm{Fe} / \mathrm{Ni}}(0.82)$. Thus, $\mathrm{Cu} / \mathrm{Zn}$ ratios appear to be "weakly plastic," $\mathrm{Fe} / \mathrm{Zn}, \mathrm{Fe} / \mathrm{Cu}$, and $\mathrm{Fe} / \mathrm{Ni}$ are "plastic" in the plant. Our results differ from previous findings [16] that Fe has higher relative stability in L. chinensis than Mn according to CV values (159\% and $479 \%$, respectively). 

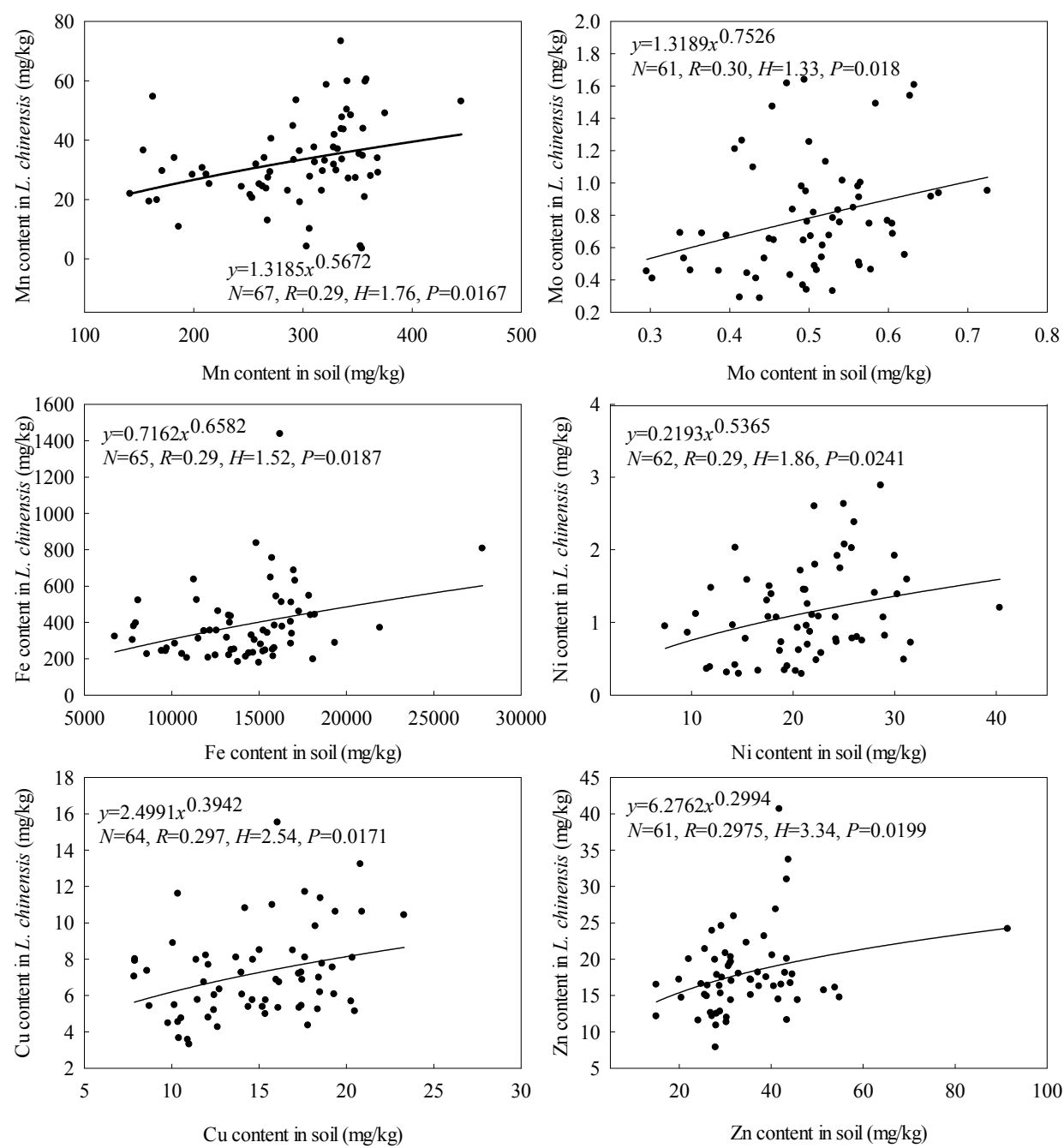

Figure 5. Elemental stoichiometric homeostasis in L. chinensis. The solid lines and circles indicate fitted curves (power) and elements, respectively. 

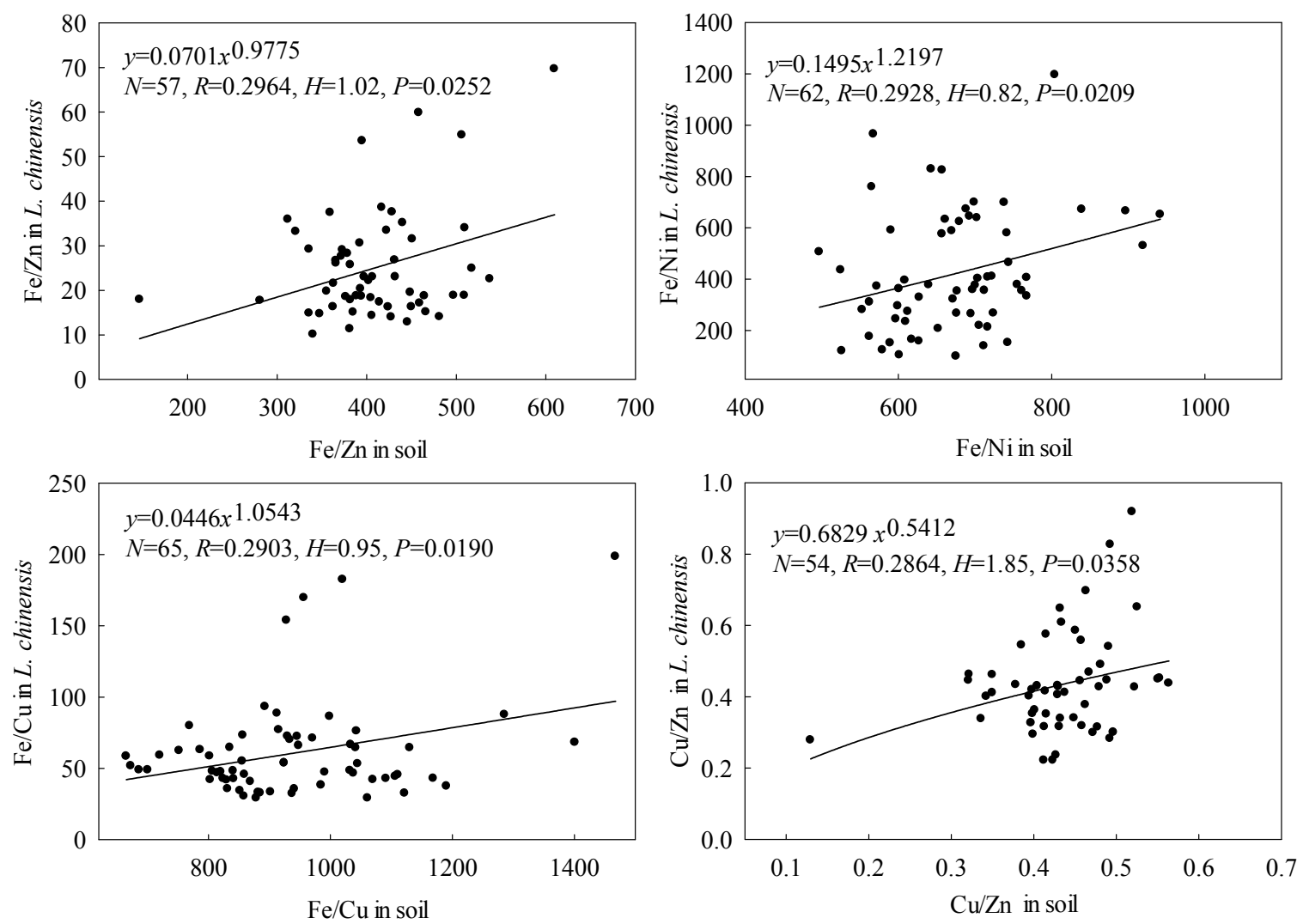

Figure 6. Elemental stoichiometric ratio homeostasis in L. chinensis. The solid lines and circles indicate fitted curves (power) and element ratios, respectively.

\section{Discussion}

Total levels of microelements provide indications of the maximum amounts of micronutrients available for plants. Their distribution in soil is the result of combined effects of numerous interacting factors, such as parent material, topography, geomorphology, climate, and fertilization level. Our results show that contents of the six microelements are lower than average values for Chinese soils in the soda saline-alkali soil of the Songnen Plain. In contrast, we found that L. chinensis plants are rich in Fe and not lacking in $\mathrm{Ni}, \mathrm{Mo}$, and $\mathrm{Cu}$. However, we detected serious $\mathrm{Mn}$ and $\mathrm{Zn}$ deficiencies in them. Our results are consistent with data from previous studies $[18,36]$. The Mn deficiency is presumably related to soil $\mathrm{pH}$ in the study area, as $\mathrm{Mn}$ contents of soil generally decrease with increases in $\mathrm{pH}$ and Mn deficiency usually occurs in soils with neutral or alkaline soil $[13,18]$. Mn deficiency usually occurs in plants growing in calcareous soils with high soil $\mathrm{pH}$, which promote $\mathrm{Mn}$ (II) oxidation to unavailable Mn (IV) [2]. However, the redox potential, organic matter content, and soil texture can also affect Mn contents. Zn deficiency can occur in various kinds of soil, but symptoms are more likely to appear in plants growing in soils with $\mathrm{pH}>6.5$, because high $\mathrm{pH}$ promotes formation of $\mathrm{Zn}$ precipitates that plants cannot use, and the solubility of $\mathrm{Zn}$ depends on its ionic forms. For example, $\mathrm{Ca}$ and $\mathrm{Mg}$ ions form insoluble calcium zincates in soda and calcareous soils under alkaline conditions [14,18]. Soils clearly prone to these problems include soda saline-alkali soils [15]. In the study area, for instance, almost all the soil samples had $\mathrm{pH}>8$ (Table 1 ).

Data presented in Figures 2-4 show that in stark contrast to $\mathrm{Fe}, \mathrm{Cu}, \mathrm{Ni}$, and $\mathrm{Mn}$ contents, Mo contents slightly increased with increases in soil $\mathrm{pH}$, total alkalinity, and $\mathrm{Na}$ contents. This is consistent with expectations, as the main factors affecting soil Mo content are soil $\mathrm{pH}$, texture, and Fe content. Mo contents generally increase with increases in $\mathrm{pH}$, and risks of Mo deficiency in plants rise with increases in soil $\mathrm{pH}$ above 6 [18]. Thus, as the soda saline-alkali soil has high $\mathrm{pH}(>8)$, the variations in Mo differ from those of the other microelements. Previous studies [15] have shown that high $\mathrm{NaHCO}_{3}$ 
contents can also induce plant $\mathrm{Zn}$ deficiency by raising the soil $\mathrm{pH}$ and thus promoting formation of $\mathrm{Zn}$ forms that plants cannot use. In contrast, we found a slight increase in plant $\mathrm{Zn}$ with increasing soil Na content (Figure 4). The reasons for this discrepancy warrant attention in future studies.

The six focal microelements play highly specific, essential roles in plant growth and development. Thus, their optimal contents and homeostatic characteristics differ. For example, several studies $[4,45]$ have indicated that $\mathrm{Zn}$ deficiency is widespread in soils around the world due to factors including high soil $\mathrm{pH}$, bicarbonate, organic matter, and phosphorus contents. Zn deficiency conditions inevitably impairs many essential Zn-dependent physiological functions, cellular homeostasis, and hence plant growth and productivity [10]. Thus, plants have evolved mechanisms that promote maintenance of appropriate $\mathrm{Zn}$ levels within them by strictly controlling Zn uptake, subcellular compartmentalization, and tissue distribution [10]. Plants have also evolved regulatory mechanisms that strictly control Fe uptake, translocation, and storage [3]. Moreover, as corroborated by the detection of abundant Fe in L. chinensis plants here, they normally absorb Fe efficiently from the soil, although it is mostly insoluble in oxidized forms [46].

Greater attention to micronutrient nutrition in global research and development plans has been strongly advocated [15]. Research on soda saline-alkali soil has focused on its treatment and improvement for many years, but plant microelements in this highly distinctive and problematic soil have not been thoroughly investigated. Thus, there are urgent needs to elucidate supplies of microelements in soda saline-alkali soil and the homeostasis of microelements in L. chinensis (and other plants in similar environments). Such efforts are essential to understand the microelement cycles in the soil-plant systems, formulate robust microfertilizer regimes, improve human nutrition, and prevent the further degradation of ecosystems with soda-alkali soil.

\section{Conclusions}

The presented data show that total $\mathrm{Fe}, \mathrm{Ni}, \mathrm{Cu}$, and Mo contents in the soda saline-alkali soil of $L$. chinensis grassland on the Songnen Plain are relatively low, while $\mathrm{Fe}, \mathrm{Ni}, \mathrm{Cu}$, and Mo contents of the L. chinensis plants are within normal ranges. However, deficiencies in $\mathrm{Mn}$ and $\mathrm{Zn}$ contents of both the soil and plants likely inhibit the plants' growth significantly. With increases in soil $\mathrm{pH}$, total alkalinity, and Na contents, the Mo contents in both soil and L. chinensis tend to increase slightly, while contents of the other microelements tend to decrease. The highest homeostatic indices obtained for microelements in L. chinensis were for $\mathrm{Zn}, \mathrm{Cu}, \mathrm{Ni}$, and $\mathrm{Cu} / \mathrm{Zn}$, indicating that there is no antagonistic interaction between $\mathrm{Cu}$ and $\mathrm{Zn}$ in L. chinensis despite the $\mathrm{Zn}$ deficiency. As a dominant species with high homeostasis, L. chinensis plays a key role in maintaining the soda saline-alkali grassland's stability, and its ecological functions could be supported by judicious application of $\mathrm{Mn}$ and $\mathrm{Zn}$ fertilizers.

Author Contributions: Y.L., H.G. and S.L. conceived and designed the study; H.G. collected samples and tested samples; Y.L. analyzed the data; Y.L. and H.G. wrote the manuscript, and Y.Z. edited it. All authors have read and agreed to the published version of the manuscript.

Funding: This work was supported by the National Natural Science Foundation of China (grant nos. 41771330, 41401339).

Conflicts of Interest: The authors declare no conflict of interest.

\section{References}

1. Clemens, S. Metal ligands in micronutrient acquisition and homeostasis. Plant Cell Environ. 2019, 42, 2902-2912. [CrossRef] [PubMed]

2. Mundus, S.; Lombi, E.; Holm, P.E.; Zhang, H.; Husted, S. Assessing the plant availability of manganese in soils using Diffusive Gradients in Thin films (DGT). Geoderma 2012, 183, 92-99. [CrossRef]

3. Wu, H.; Ling, H.Q. FIT-binding proteins and their functions in the regulation of Fe homeostasis. Front. Plant Sci. 2019, 10, 844. [CrossRef] [PubMed]

4. Caldelas, C.; Weiss, D.J. Zinc homeostasis and isotopic fractionation in plants: A review. Plant Soil 2016, 411, 17-46. [CrossRef] 
5. Wang, S.P.; Wang, Y.F.; Hu, Z.Y.; Chen, Z.Z.; Fleckenstein, J.; Schnug, E. Status of iron, manganese, copper, and zinc of soils and plants and their requirement for ruminants in Inner Mongolia steppes of China. Commun. Soil Sci. Plant Anal. 2011, 34, 655-670. [CrossRef]

6. Guo, X.Y.; Zuo, Y.B.; Wang, B.R.; Li, J.M.; Ma, Y.B. Toxicity and accumulation of copper and nickel in maize plants cropped on calcareous and acidic field soils. Plant Soil 2010, 333, 365-373. [CrossRef]

7. Rutkowska, B.; Szulc, W.; Spychaj-Fabisiak, E.; Pior, N. Prediction of molybdenum availability to plants in differentiated soil conditions. Plant Soil Environ. 2017, 63, 491-497.

8. McGrath, S.P.; Mico, C.; Curdy, R.; Zhao, F.J. Predicting molybdenum toxicity to higher plants: Influence of soil properties. Environ. Pollut. 2010, 158, 3095-3102. [CrossRef]

9. Zhang, X.P.P.; Deng, W.; Yang, X.M.M. The background concentrations of 13 soil trace elements and their relationships to parent materials and vegetation in Xizang (Tibet), China. J. Asian Earth Sci. 2002, 21, 167-174. [CrossRef]

10. Pita-Barbosa, A.; Ricachenevsky, F.K.; Wilson, M.; Dottorini, T.; Salt, D.E. Transcriptional plasticity buffers genetic variation in zinc homeostasis. Sci. Rep. 2019, 9, 19482. [CrossRef]

11. Yan, Z.; Zhao, X.; Yang, F.; Zeng, Z.; Liu, Y.; Liu, F. Effect of restoration interference techniques on vegetation and soil carbon discharge of saline-alkali grassland. Terr. Nat. Resour. Study 2014, 6, 55-58.

12. Zhou, X.; Guo, J.; Zhao, J. Dynamics of nutrient element iron in soil-plant ecosystem of the Songnen Plain Leymus chinensis grassland. Chin. J. Appl. Ecol. 2004, 15, 2250-2254.

13. Zhou, X.; Guo, J.; Li, Y. Dynamic distribution of Mn element between soil and plant in Leymus chinensis grassland in Songnen Plains of China. J. Northeast For. Univ. 2008, 36, 36-38.

14. Zhou, X.; Guo, J.; Wang, Y.; Zhou, T. Dynamics of Zn between soil and plant in Northeast Leymus chinensis grassland. J. For. Res. 2006, 17, 206-210. [CrossRef]

15. Qi, C.; Liang, Z. Review of zinc supply and plant zinc nutrition of soda-alkaline soils in Songnen Plain. Syst. Sci. Compr. Studies Agric. 2010, 26, 378-384.

16. Han, W.X.; Fang, J.Y.; Reich, P.B.; Woodward, F.I.; Wang, Z.H. Biogeography and variability of eleven mineral elements in plant leaves across gradients of climate, soil and plant functional type in China. Ecol. Lett. 2011, 14, 788-796. [CrossRef]

17. Sterner, R.W.; Elser, J.J. Ecological Stoichiometry: The Biology of Elements from Molecules to the Biosphere; Princeton University Press: Princeton, NJ, USA, 2002.

18. Wang, D.; Fu, D. Available evaluation of soil trace elements in the west area of Jilin Province. Soil 2002, 2, 86-93.

19. Chang, J.; Ge, Y. Studies on the interrelative absorption of the main nutrient elements in Leymus chinensis community. Chin. Bull. Bot. 1995, 12, 136-141.

20. Mu, Y.; Geng, Y. The element content characteristics of main species in Leymus Chinensis grassland in Inner Mongolia, China. Ecol. Environ. Sci. 2015, 24, 1118-1124.

21. Karimi, R.; Folt, C.L. Beyond macronutrients: Element variability and multielement stoichiometry in freshwater invertebrates. Ecol. Lett. 2006, 9, 1273-1283. [CrossRef]

22. Yu, Q.; Chen, Q.S.; Elser, J.J.; He, N.P.; Wu, H.H.; Zhang, G.M.; Wu, J.G.; Bai, Y.F.; Han, X.G. Linking stoichiometric homoeostasis with ecosystem structure, functioning and stability. Ecol. Lett. 2010, 13, 1390-1399. [CrossRef] [PubMed]

23. Yu, Q.; Elser, J.J.; He, N.; Wu, H.; Chen, Q.; Zhang, G.; Han, X. Stoichiometric homeostasis of vascular plants in the Inner Mongolia grassland. Oecologia 2011, 166, 1-10. [CrossRef] [PubMed]

24. Li, Y.; Li, Q.; Liu, H.; Li, S.; Wang, Y.; Liu, Y. Ecological stoichiometry-based study of the influence of soil saline-alkali stress on nutrient homeostasis in L. chinensis. Ecotoxicol. Environ. Saf. 2018, 165, 243-249. [CrossRef] [PubMed]

25. Li, Y.; Li, Q.; Guo, D.; Liang, S.; Wang, Y. Ecological stoichiometry homeostasis of Leymus chinensis in degraded grassland in western Jilin Province, NE China. Ecol. Eng. 2016, 90, 387-391. [CrossRef]

26. Amini, S.; Ghadiri, H.; Chen, C.; Marschner, P. Salt-affected soils, reclamation, carbon dynamics, and biochar: A review. J. Soils Sediments 2016, 16, 939-953. [CrossRef]

27. Güsewell, S. N: P ratios in terrestrial plants: Variation and functional significance. New Phytol. 2004, 164, 243-266. [CrossRef] 
28. Zhao, Q.; Tang, J.; Li, Z.; Yang, W.; Duan, Y. The influence of soil physico-chemical properties and enzyme activities on soil quality of saline-alkali agroecosystems in western Jilin Province, China. Sustainability 2018, 10, 1529. [CrossRef]

29. Li, Y.F.; Liang, S.; Zhao, Y.Y.; Li, W.B.; Wang, Y.J. Machine learning for the prediction of L. chinensis carbon, nitrogen and phosphorus contents and understanding of mechanisms underlying grassland degradation. J. Environ. Manage. 2017, 192, 116-123. [CrossRef]

30. Lu, R.K. Analytical Methods for Soil and Agro-Chemistry; China Agricultural Science and Technology Press: Beijing, China, 2000.

31. Liu, Z. Agricultural Chemistry of Microelements; Chinese Agricultural Press: Beijing, China, 1991; p. 19.

32. Zou, B.; He, X. Nutrition of Plants; Agriculture Press: Beijing, China, 1985; pp. 314-323.

33. Zhang, X.; Zhang, F.; Li, C. Essential micronutrients for plant growth-nickel. Soil 1996, 4, 176-179.

34. Hao, Z.; Wu, Y. Nutritional feature of trace elements in soil, forage and animal from Hexi semi-desert area. Acta Pratac. Sin. 1993, 2, 39-44.

35. Yan, B.; Liu, G.; Fan, B.; He, G.; Shi, L.; Li, J.; Ji, Z. Relationships between plant stoichiometry and biomass in an arid-hot valley, Southwest China. Chin. J. Plant Ecol. 2015, 39, 807-815.

36. Zhou, X. Study on the Main Microelements between Soil, Grass and Livestock in Leymus chinensis Grassland of Songnen Plain. Ph.D. Thesis, Northeast Normal University, Changchun, China, 2004.

37. Li, Z.; Zhu, Q. Micronutrient Fertilizer; Jiangsu Science and Technology Press: Nanjing, China, 1991; p. 104.

38. Munns, R.; Tester, M. Mechanisms of salinity tolerance. Annu. Rev. Plant Biol. 2008, 59, 651-681. [CrossRef] [PubMed]

39. Almeida, D.M.; Oliveira, M.M.; Saibo, N.J.M. Regulation of $\mathrm{Na}^{+}$and $\mathrm{K}^{+}$homeostasis in plants: Towards improved salt stress tolerance in crop plants. Genet. Mol. Biol. 2017, 40, 326-345. [CrossRef]

40. Liang, W.; Ma, X.; Wan, P.; Liu, L. Plant salt-tolerance mechanism: A review. Biochem. Biophys. Res. Commun. 2018, 495, 286-291. [CrossRef] [PubMed]

41. Munns, R. Comparative physiology of salt and water stress. Plant Cell Environ. 2002, 25, 239-250. [CrossRef] [PubMed]

42. Niu, X.; Bressan, R.A.; Hasegawa, P.M.; Pardo, J.M. Ion homeostasis in NaCl stress environments. Plant Physiol. 1995, 109, 735-742. [CrossRef] [PubMed]

43. Jumberi, A.; Yamada, M.; Yamada, S.; Fujiyama, H. Salt tolerance of grain crops in relation to ionic balance and ability to absorb microelements. Soil Sci. Plant Nutr. 2001, 47, 657-664. [CrossRef]

44. Persson, J.; Fink, P.; Goto, A.; Hood, J.M.; Jonas, J.; Kato, S. To be or not to be what you eat: Regulation of stoichiometric homeostasis among autotrophs and heterotrophs. Oikos 2010, 119, 741-751. [CrossRef]

45. Henriques, A.R.; Chalfun-Junior, A.; Aarts, M. Strategies to increase zinc deficiency tolerance and homeostasis in plants. Braz. J. Plant Physiol. 2012, 24,3-8. [CrossRef]

46. Rodriguez-Celma, J.; Chou, H.; Kobayashi, T.; Long, T.A.; Balk, J. Hemerythrin E3 ubiquitin ligases as negative regulators of iron homeostasis in plants. Front. Plant Sci. 2019, 10, 98. [CrossRef]

(C) 2020 by the authors. Licensee MDPI, Basel, Switzerland. This article is an open access article distributed under the terms and conditions of the Creative Commons Attribution (CC BY) license (http://creativecommons.org/licenses/by/4.0/). 